\title{
An Evaluative Checklist for Reviewing a College Library Program
}

Editor's Note: At the ALA Annual Conference in June 1979 the ACRL Board of Directors approced the recommendation of the Standards and Accreditation Committee that "An Evaluative Checklist for Revieuing a College Library Program" be adopted as a supplement to "Standards for College Libraries." The Standards and Accreditation Committee deceloped the checklist and then e'caluated it by asking a representatice sample of fifty college libraries to test it in the fuld. The checklist appears in this issue of C\&RL New's for the information of ACRL members

\section{INTRODUCTION}

The Evaluative Checklist is based on the 1975 "Standards for College Libraries" developed by the Association of College and Research Libraries, a division of the American Library Association. The standards "describe a realistic set of conditions which, if fulfilled, will provide an adequate library program in a college. They attempt to synthesize and articulate the aggregate experience and judgment of the academic library profession as to adequacy in library resources, services, and facilities for a college community."1 The standards cover libraries serving academic programs at the bachelor's and master's degree levels as defined by the Carnegie Commission on Higher Education as Liberal Arts Colleges I and 11 and Comprehensive Universities and Colleges I and II. ${ }^{2,3}$ The checklist has been validated and field-tested. When properly applied it will discriminate among the several levels of quality in library programs.

The status of a library program is not likely to be known without periodic evaluation. Before

1. "Standards for College Libraries," College d Research Libraries News 36:277 (Oct. 1975).

2. Carnegie Foundation for the Advancement of Teaching, A Classification of Institutions of Higher Education (Berkeley, Calif.: The Foundation, 1973).

3. Libraries serving junior and community colleges should consult: “AAJC-ACRL Guidelines for Two-Year College Library Learning Resource Centers," College d- Research Libraries Neus 33:305-15 (Dec. 1972).

Recently developed L'niversity Library Standards cover libraries serving comprehensive universities: ARL/ACRL Joint Committee on University Library Standards, "University" Library Standards," College d- Research Libraries Neus 40:101-10 (April 1979). completing the checklist, the evaluator should review the Application Procedures and Directions for Use that precede the checklist. He or she may also wish to study the text of the "Standards for College Libraries" covered by the checklist.

The checklist follows the organization of the standards stated at the head of the following sections:

1. Objectives

2. Collections

3. Organization of Materials

4. Staff

5. Delivery of Service

6. Facilities

7. Administration

8. Budget

It is acknowledged that it would be desirable to include more precise measures of library effectiveness and productivity, nonprint resources and services, and program evaluation in the checklist. However, there is no consensus among academic librarians for their preparation at this time.

\section{Application Procedires}

Evaluation in general is a process, a complex of tools, used to produce a picture of what's happening, with some further goals in mind. The primary concern of the checklist is with evaluating how well a college library is performing some of its key functions to enable it to chart a course for improvement. The collection of checklist scores without providing the evaluators with operational information, analyzing accurately the results, and formulating appropriate recommendations will result in a simplistic comparison rather than producing a framework for improving library services. To accomplish its purpose, the checklist should be the instrument of an evaluating process which includes the following components-

1. Widespread participation and input of the total college community in the evaluation of library programs, and the review of the results.

2. The evaluators' review and understanding of the broad goals and specific objectives of the college and its library.

3. The use of the Evaluative Checklist in recording judgments concerning levels of library services.

4. The collection of information not furnished by the checklist which describes program of fectiveness in terms of the objectives set forth. 
5. The interpretation of the results and drawing of conclusions which furnish information about the growth, progress, and effectiveness of the library's programs.

6. The formulation of recommendations that will support revised objectives and improve library services.

The college community and its library evaluators should be aware of the limitations of any evaluating process. These include the coverage of the evaluating instrument (the checklist does not pretend to cover everything), and the objectivity of the evaluation process. Judgmental decisions are involved throughout all phases of the evaluation as the participants adjust their activities in terms of the feedback received. An alert evaluator is aware of the influence of his or her own experience, the impact of personalities, and potential errors in methodology, data collection, and interpretation. The community itself, and the library in particular, are in the best position to evaluate what the study means, and to utilize it in improving library programs.

\section{DIRECTIONS FOR USE}

Circle one of the numbers at the left of the statement that most accurately represents conditions in the library you are evaluating. If a statement accurately describes the library, circle the middle number $(2,5,8$, or 11$)$ at the left of that statement. If you think conditions are below what is described, circle the higher number $(3,6,9$, or 12). If the conditions at the library are above, circle one of the lower numbers $(1,4,7$, or 10$)$. Circle only one of the numbers in the 1 to 12 grouping.

\section{EXAMPLE}

Standard 5: Delivery of Service

\section{A. Library Instruction}

$\begin{array}{llll}1 & 2 & 3 & \text { Librarians routinely work closely }\end{array}$ with the teaching faculty in identifying instructional needs and teach the use of library resources and services to meet these needs.

$4 \quad 5 \quad 6 \quad$ Librarians are regularly called on for consultative assistance and instruction in the use of library resources and services.

$\begin{array}{llll}7 & 8 & 9 & \text { Librarians provide consultative as- }\end{array}$ sistance in the use of library resources and services when requested and free from other duties.

$\begin{array}{llll}10 & 11 & 12 & \text { Librarians are rarely available to }\end{array}$ provide library instruction services.

Directions for use and interpretation of the Profile graph accompany the Profile on pages $313-15$

\section{Evallative Checklist}

\section{Standard 1: Objectives of the Library}

1 The college library shall develop an explicit statement of its objectives in accord with the goals and purposes of the college.

1.1 The development of library objectives shall be the responsibility of the library staff, in consultation with students, members of the teaching faculty, and administrative officers.

1.2 The statement of library objectives shall be reviewed periodically and revised as needed.

(Circle only one of the twelve numbers)

$\begin{array}{llll}1 & 2 & 3 & \text { The college library's statement of }\end{array}$ objectives is conceived and formulated within the overall academic purpose of the college, is recognized by the college community as supporting its educational goals and instructional needs, and is kept current through periodic reviews and revisions by the library faculty, teaching faculty, and administrative staff.

$\begin{array}{llll}4 & 5 & 6 & \text { The library's statement of objec- }\end{array}$ tives generally conforms with the overall academic purpose of the college, but requires minor revisions or better dissemination so that all members of the college community can understand and evaluate the appropriateness and effectiveness of library services.

$\begin{array}{llll}7 & 8 & 9 & \text { The college library's statement of }\end{array}$ objectives requires substantial revision and updating to coordinate it with the educational goals and instructional needs of the college.

$\begin{array}{llll}10 & 11 & 12 & \text { The college library does not have a }\end{array}$ statement of objectives conceived and formulated within the overall academic purpose of the college and consistent with the institution's educational goals and instructional needs.

\section{Standard 2: The Collections}

2 The library's collections shall comprise all corpora of recorded information owned by the college for educational, inspirational, and recreational purposes, including multi-dimensional, aural, pictorial, and print materials.

2.1 The library shall provide quickly a high percentage of such material needed by its patrons.

2.1.1 The amount of print materials to be thus provided shall be determined by Formula A (see Appendix) which takes into account the nature and extent of the academic pro- 
gram of the institution, its enrollment, and the size of its teaching faculty.

\section{A. Availability of Library Materials*}

123 The library acquires, organizes, stores, and delivers for use within, or circulation from, the library all college-owned forms of recorded information required to support the college's educational programs and interests.

$\begin{array}{llll}4 & 5 & 6 & \text { The library acquires and organizes }\end{array}$ most college-owned recorded information, but the delivery of this information is somewhat restricted by storage and access conditions at the library or other campus locations.

$\begin{array}{llll}7 & 8 & 9 & \text { College-owned materials required }\end{array}$ to support several curriculum areas of the college are not acquired and organized by the library, and delivered through its services.

101112 A substantial corpus of collegeowned recorded information is not acquired, organized, stored, and delivered for use within, or circulated from, the library

\section{B. Accessibility of Library Materials*}

$\begin{array}{llll}2 & 2 & \text { The library is able to deliver, from }\end{array}$ its own collection or via interlibrary systems, a substantial quantity of materials satisfying the user's needs and assignment schedules.

456 The library is frequently able to deliver, from its own collection or via interlibrary systems, a sufficient quantity of materials satisfying the user's needs and assignment schedules.

$\begin{array}{llll}7 & 8 & 9 & \text { The quantity/quality of available li- }\end{array}$ brary materials is uneven, thereby limiting the library's ability to supply materials requested, or to deliver them without significant delays.

$1011 \quad 12$ The quantity/quality of library materials is so limited that the library is unable to supply many materials requested, or deliver them without intolerable delays.

\section{Selection of Materials*}

$\begin{array}{llll}1 & 2 & 3 & \text { The library selects an adequate }\end{array}$ portion of the bibliography of the disciplines represented by the curriculum, appropriate in quantity to both the level of instruction and to the number of students and faculty who use it. The collection's annual

*Circle only one of the twelve numbers. growth rate, before withdrawals, exceeds 5 percent.

$\begin{array}{llll}4 & 5 & 6 & \text { The library collection generally }\end{array}$ supports the college's curriculum and interests except for the need to improve coverage in a few subject areas. The annual growth rate approaches 5 percent.

$\begin{array}{llll}7 & 8 & 9 & \text { The library collection is uneven in }\end{array}$ its support of the college's curriculum and interests. Basic collections should be developed for several disciplines

101112 The library collection is generally inadequate in its support of the college's academic program. A substantial portion of titles listed in standard, scholarly bibliographies, or considered by the faculty as supporting their instructional needs, are not represented in the library collection.

\section{Withdrawal of Materials *}

123 Continuous evaluation of the collection provides for the withdrawal of materials which do not contribute to the college's current or anticipated academic programs

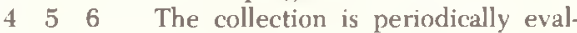
uated to identify outdated or nonsupportive materials. More frequent reviews are required in a few subject areas.

$\begin{array}{llll}7 & 8 & 9 & \text { Several subject collections contain }\end{array}$ much material which should be withdrawn because it is outdated or nonsupportive of current or anticipated academic programs.

$1011 \quad 12$ The collection generally contains material which has outlived its usefulness to the college's programs.

\section{E. Quantity of Materials *}

Using Formula A (see Appendix) for calculating the number of relevant print volumes (or microform volume-equivalents) to which the library should provide prompt access-

$\begin{array}{llll}1 & 2 & 3 & \text { The library can provide promptly }\end{array}$ 90-100 percent called for.

456 The library can provide promptly $80-90$ percent called for

$\begin{array}{llll}7 & 8 & 9 & \text { The library can provide promptly }\end{array}$ 65-70 percent called for.

$1011 \quad 12$ The library can provide promptly 50-64 percent called for.

\section{Standard 3: Organization of Materials}

Library collections shall be organized by nationally approved conventions and arranged for efficient retrieval at time of need. 
3.1 There shall be a union catalog of the library's holdings that permits identification of items, regardless of format, by author. title, and subject.

3.1.1 The catalog may be developed either by a single library or jointly among several libraries.

3.1.2 The catalog shall be in a format that can be consulted by a number of people concurrently and at time of need.

3.1.3 In addition to the catalng there shall also be requisite subordinate files, such as serial records, shelf lists, authority files, and indexes to nonmonographic materials.

3.2 Except for certain categories of material which are for convenience best segregated by form. library materials shall be arranged on the shelves by subject.

3.2. I Patrons shall have direct access to library materials on the shelves.

\section{A. Indexing of Library Materials *}

123 The library has a bibliographic control system for the classification, bibliographic identification, location, and retrieval of all library materials which conforms to national conventions and includes author, title, and subject entries.

456 The library has a bibliographic control system that is adequate most of the time, but excludes some materials according to form or location

789 The college community reports some difficulties in identifying, locating, and retrieving specific library materials because of deficiencies in the organization and coverage of the bibliographic control system

10 $11 \quad 12$ Library materials are consistently difficult to identify, locate, and retrieve because the bibliographic control system requires major reorganization

\section{B. Arrangement of Library Materials *}

$\begin{array}{llll}1 & 2 & 3 & \text { Most library materials are arranged }\end{array}$ on the shelves by subject and the college community locates, browses, and selects these materials with ease.

456 Library materials are generally arranged on open shelves by subject, although the complexities of classification or storage arrangements of some materials reduce easy access to them.

789 The complexities or disorganization of the arrangement of library materials discourage the college community from using the materials.

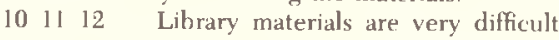

*Circle only one of the twelve numbers. to locate and retrieve, and their inaccessibility seriously deters their optimum use.

\section{Standard 4: Staff}

4 The library staff shall be of adequate size and quality to meet agreed-upon objectives.

4.1 The staff shall comprise qualified librarians, skilled supportive personnel, and part-time assistants serving on an hourly basis.

4.2 The marks of a librarian shall include a graduate library degree from an ALAaccredited program, responsibility for duties of a professional nature, and participation in professional library affairs beyond the local campus.

4.2.1 The librarians of a college shall be organized as an academic department-or, in the case of a university, as a school-and shall administer themselves in accord with ACRL "Standards for Faculty Status for College and University Librarians" (sece Appendix II [of "Standards for College Libraries"]).

4.3 The number of librarians required shall be determined by a formula (Formula B, [Appendix]) which takes into account the enrollment of the college and the size and growth rate of the collections.

4.3.1 There shall be an appropriate balance of effort among librarians, supportive personnel, and part-time assistants, so that every staff member is employed as nearly as possible commensurate with his library training, experience, and capability

4.4 Library policies and procedures concerning staff shall be in accord with sound personnel management practice.

\section{A. Staff Size*}

123 The library has sufficient professional, technical, and clerical staff to provide satisfactory services meeting the library's objectives. Using Formula B (see Appendix) for calculating the number of librarians, the library provides $90-100$ percent of the requirements.

456 Using Formula B for calculating the number of librarians, the library provides $75-90$ percent of the requirements.

$\begin{array}{llll}7 & 8 & 9 & \text { Using Formula B for calculating }\end{array}$ the number of librarians, the library provides 55-74 percent of the requirements.

101112 Using Formula B for calculating the number of librarians, the library provides 40-54 percent of the requirements. 


\section{B. Professional Responsibilities*}

$\begin{array}{llll}1 & 2 & 3 & \text { Leadership and instructional and }\end{array}$ consultative services are provided by qualified librarians who have faculty status and administer themselves in accord with the ACRL "Standards for Faculty Status for College and University Librarians."

456 The administration and delivery of library services are provided by gualified librarians recognized and supported by the college, but without full coverage of the ACRL "Standards for Faculty Status.

789 The responsibility for library services is delegated to librarians without professional status and departmental organization.

I0 $11 \quad 12$ The responsibility for administering library services is assigned $t)$ institutional staff members not qualified as librarians.

\section{Support Staff*}

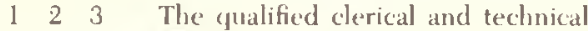
staff is sufficient in number, with assignment of responsibilities commensurate with job reguirements, training, and experience.

456 Clerical and technical assistance is usually sufficient. Mismatching of joh assignments among clerical and professional staff infrequently occurs.

789 Clerical and technical assistance is available, but there are frequent shortages or mismatching of job assignments among support and professional staff.

$\begin{array}{llll}10 & 11 & 12 & \text { Clerical and technical assistance is }\end{array}$ generally' not available.

\section{Personnel Management*}

123 Written policies and procedures consistent with the goals and responsibilitie's of the college direct the recruiting, appointment, training, evaluation, promotion and tenure, or dismissal of the library staff.

456 Library personnel policies are consistent with the goals and responsibilities of the college, although sereral procedures recuuire revision and updating.

789 Library personnel policies are frequently inconsistent with the goals and responsibilities of the college. Policy and procedural improvements are necessiary.

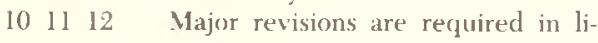

*Circle only one of the twelve numbers. brary personnel policies and procedures to establish sound management practices

\section{Standard 5: Delivery of Service}

5 The college library shall establish and maintain a range and quality of services that will promote the academic program of the institution and encourage optimal library use

5.1 Proper service shall include: the provision of continuing instruction to patrons in the effective exploitation of libraries; the guidance of patrons to the library materials they need: and the provision of information to patrons as appropriate.

5.2 Library materials shall be circulated to qualified patrons under e'cuitable policies and for as long periods as possible without jeopardizing their availability to others

5.2.1 The availability of reading materials shall be extended wherever possible by the provision of inexpensive means of photocopying.

5.2.2 The quality of the collections available lo cally to patrons shall be enhanced through the use of "National Interlibrary Loan Code, 1968" (see Appendix I] [of "Standards for College Libraries"]) and other cooperative agreements which provide reciprocal access to multi-library resources

5.3 The hours of public access to the materials on the shelves, to the study facilities of the library, and to the library statt shall be consistent with reasonable demand, both during the normal study week and during weekends and vacation periods.

5.4 Where academic programs are offered away from a campus, library services shall be provided in accord with AC:RL's "Guidelines for Library Services to Extension Students" (see Appendix II [of "Standards for College Lihraries"]).

\section{A. Library Instruction*}

123 Librarians routinely work closely with the teaching faculty in identifying instructional needs and teach the use of library resources and services to meet these needs.

456 Librarians are regularly called on for consultative assistance and instruction in the use of library resources and services.

$7 \quad 89$ Librarians provide consultative assistance in the use of library resources and services when requested and free from other duties.

101112 Librarians are rarely available to provide library instruction services. 


\section{B. Information Services*}

$\begin{array}{llll}1 & 2 & 3 & \text { The library staff provides a variety }\end{array}$ of information, instruction, and interpretative services, and meets most of its community's demands for these services.

$\begin{array}{llll}4 & 5 & 6 & \text { The library staff provides a variety }\end{array}$ of information, instruction, and interpretative services, but is unable to meet some demands for these services.

$\begin{array}{llll}7 & 8 & 9 & \text { Limited information services are }\end{array}$ available to the college community, and may be restricted to certain clientele.

$1011 \quad 12$ Information services are not available to the college community.

\section{Circulation*}

123 Uniformly administered circulation policies regulate use of library materials for periods that are reasonable without jeopardizing the college community's access to materials.

456 Circulation policies regulate the use of library materials for periods that are usually acceptable. A review of the policies is desirable to correct minor problems.

$\begin{array}{llll}7 & 8 & 9 & \text { Circulation policies are frequently }\end{array}$ restrictive without cause. Regulations are confusing and inconsistently administered.

101112 Circulation policies do not facilitate access to library materials, and are poorly administered.

\section{Access to Multi-Library Resources*}

$1 \quad 2 \quad 3$ The library efficiently delivers materials and services provided by local, state, and national libraries via interlibrary loan codes and joint access consortia to students, faculty, and staff.

$\begin{array}{llll}4 & 5 & 6 & \text { The library delivers materials and }\end{array}$ services provided by other libraries to students, faculty, and staff, but delays and/or access difficulties sometimes restrict service effectiveness.

$\begin{array}{llll}7 & 8 & 9 & \text { The library delivers materials and }\end{array}$ services provided by other libraries only to selected individuals or groups in the academic community.

101112 The library seldom provides its college community with access to the materials and services of other libraries.

\section{E. Hours*}

123 The number of hours per week that

* Circle only one of the twelve numbers. library services and facilities are available meets the study and research needs of the college community.

456 Library hours are usually responsive to the community's needs for library services and facilities. There are requests for minor changes in these hours.

$\begin{array}{llll}7 & 8 & 9 & \text { There are periods during the week }\end{array}$ (e.g., evenings, weekends) and the academic year (e.g., vacations, exams) when library hours are not responsive to the community's needs.

101112 An insufficient number of library hours seriously deters the college community from achieving its educational goals.

\section{Standard 6: Facilities}

6 The college shall provide a library building containing secure facilities for housing its resources, adequate space for administration of those resources by staff, and comfortable quarters and furnishings for their utilization by patrons.

6.1 The size of the library building shall be determined by a formula (see Formula C [Appendix]) which takes into account the enrollment of the college, the extent and nature of its collections, and the size of its staff.

6.2 The shape of the library building and the internal distribution of its facilities and services shall he determined by function.

6.3 Except in unusual circumstances, the college library's collections and services shall be administered within a single structure.

\section{A. The Building*}

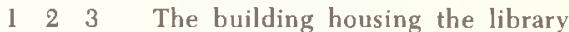
collection and services is fully equipped to support a quality program, functional in arrangement, accommodating to users and staff, and flexible in accommodating growth needs.

$\begin{array}{llll}4 & 5 & 6 & \text { The design and arrangement of the }\end{array}$ library building generally supports service, storage, and growth requirements, but would be improved by renovations, expansions, or rearrangement.

$\begin{array}{llll}7 & 8 & 9 & \text { The library building has a number }\end{array}$ of deficiencies which limit its contribution to and support of library services.

101112 The library building is deficient in several critical areas, e.g., storage space, security, service, facilities, efficient design. These deficiencies 
seriously handicap the library in its delivery of service to the community.

B. Building Size*

Using Formula C (see Appendix) for calculating the net assignable area necessary for all library services except non-book services-

I 23 The library's facilities provide 90-100 percent of the space called for.

456 The library's facilities provide 75-90 percent of the space called for.

$\begin{array}{llll}7 & 8 & 9 & \text { The library's facilities provide }\end{array}$ 60-74 percent of the space called for.

101112 The library's facilities provide 50-59 percent of the space called for.

\section{Standard 7: Administration}

7 The college library shall be administered in a manner which permits and encourages the fullest and most effective use of available library resources.

7.1 The statutory or legal foundation for the library's activities shall be recognized in writing.

7.2 The college librarian shall be a member of the library faculty and shall report to the president or the chief academic officer of the institution.

7.2.1 The responsibilities and authority of the college librarian and procedures for his appointment shall be defined in writing

7.3 There shall be a standing advisory committee comprising students and members of the teaching faculty which shall serve as the main channel of formal communication between the library and its user community.

7.4 The library shall maintain written policies and procedure manuals covering internal library governance and operational activities.

7.4.1 The library shall maintain a systematic and continuous program for evaluating its performance and for identifying needed improvements.

7.4.2 The library shall develop statistics not only for purposes of planning and control but also to aid in the preparation of reports designed to inform its publics of its accomplishments and problems.

7.5 The library shall develop, seek out, and utilize cooperative programs for purposes of either reducing its operating costs or enhancing its services, so long as such programs create no unreimbursed or unreciprocated costs for other libraries or organizations.

7.6 The library shall be administered in accord

"Circle only one of the twelve numbers. with the spirit of the ALA "Library Bill of Rights" (see Appendix II [of "Standards for College Libraries"]).

\section{A. Administration of the Library*}

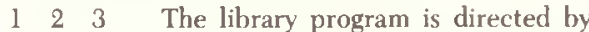
a well-qualified librarian with faculty appointment who administers library services which support the full range of the college's educational program.

456 The library program is directed by a well-qualified librarian; a better orientation of library services to the college's educational program is desirable

$\begin{array}{llll}7 & 8 & 9 & \text { The library director does not at }\end{array}$ tend to the full range of the library's responsibilities, and a review of the causes should be initiated.

101112 The college community generally believes the library is not serving its educational program, and a major reorganization appears desirable.

\section{B. Organization Authority*}

I 23 The library's responsibilities and flow of authority under which it is empowered to act are described in official college documents such as bylaws, trustee documents, or public laws.

$\begin{array}{llll}4 & 5 & 6 & \text { The library's responsibilities and }\end{array}$ flow of authority under which it is empowered to act are described in official college documents such as organizational charts, reporting structure diagrams, and job descriptions.

$\begin{array}{llll}7 & 8 & 9 & \text { The library's responsibilities and }\end{array}$ flow of authority are inadequately covered by official college and administrative documents.

$1011 \quad 12$ The library's responsibilities and flow of authority are not covered in official college and administrative documents.

\section{Librarian's Authority *}

$\begin{array}{llll}1 & 2 & 3 & \text { The scope and nature of the college }\end{array}$ librarian's duties and powers, the procedures for his appointment, and the focus of his reporting responsibilities are defined in writing.

456 Some of the college librarian's duties and powers, appointment procedures, and reporting responsibilities are defined in writing.

$\begin{array}{llll}7 & 8 & 9 & \text { The written description of the re- }\end{array}$ sponsibilities and authority of the college librarian is generally inadequate and incomplete.

101112 There is a minimal or no written description of the responsibilities and authority of the college librarian. 


\section{Reporting Structure*}

$\begin{array}{llll}1 & 2 & 3 & \text { The college librarian reports to }\end{array}$ either the president or the chief officer in charge of academic affairs of the college

456 The college librarian reports to the office of academic affairs, but does not always review reports and recommendations with the chief academic officer

$\begin{array}{llll}7 & 8 & 9 & \text { The college librarian reports to a }\end{array}$ learning resources director or dean who reports to the chief academic officer.

$\begin{array}{llll}10 & 11 & 12 & \text { No person has been given the ad- }\end{array}$ ministrative responsibility for receiving reports from the college librarian.

\section{E. Library Committee*}

$1 \quad 2 \quad 3 \quad$ A committee composed of representatives of the college community meets regularly to advise the librarian on matters of policy, user needs, and concerns, and effectively assists the community in understanding the library's capabilities and problems.

456 A committee composed of representatives of the college community advises the librarian on policy matters, user needs, and concerns, and conveys library information to the community. Its effectiveness could be improved.

$\begin{array}{llll}7 & 8 & 9 & \text { A committee meets to advise the }\end{array}$ librarian on policy matters, user needs, and concerns, but is frequently ineffective as a channel of communication between the library and its community.

101112 There is no committee or representative group to advise the librarian and channel communications between the library and its community.

\section{F. Policy and Procedure Records*}

$\begin{array}{llll}1 & 2 & 3 & \text { Written policies and procedure }\end{array}$ manuals assuring uniformity and consistency of action and aiding staff training cover most of the library's technical and reader service operations.

$4 \quad 5 \quad 6 \quad$ Written policies and procedure manuals cover many of the library's operations, but several require revision and updating to incorporate policy and procedural changes.

$\begin{array}{llll}7 & 8 & 9 & \text { A number of library operations re- }\end{array}$ quire written policies and procedure manuals to assist administrative and training activities.

${ }^{*}$ Circle only one of the twelve numbers.
$1011 \quad 12$ Generally the library does not have written policies and procedure manuals.

\section{G. Evaluation of Services*}

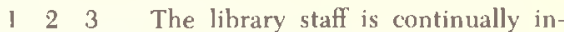
volved in monitoring and evaluating the productivity, use of, and needs for library services, and uses this information to revise and develop library programs.

$4 \begin{array}{llll}4 & 5 & 6 & \text { The library periodically monitors }\end{array}$ and evaluates its services and reviews user needs, and uses this information in program revisions and development.

$\begin{array}{llll}7 & 8 & 9 & \text { The library conducts evaluations of }\end{array}$ its services and reviews user needs only in response to critical problems, or to provide data for reports.

$\begin{array}{llll}10 & 11 & 12 & \text { Evaluations of library services and }\end{array}$ user needs are rarely conducted by the library, or used in program planning.

\section{H. Public Relations*}

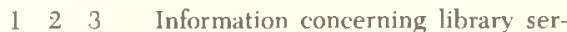
vice accomplishments and problems is regularly disseminated to the faculty, students, and administration. The forms of this information include news releases, reports, handbooks, brochures, reading lists, and displays.

$\begin{array}{llll}4 & 5 & 6 & \text { Information concerning library ser- }\end{array}$ vices is occasionally disseminated to faculty, students, and staff or by request.

$\begin{array}{llll}7 & 8 & 9 & \text { Information concerning library ser- }\end{array}$ vices is seldom disseminated to the community, but is sometimes supplied upon request.

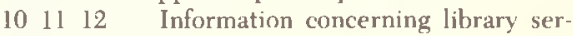
vices is rarely disseminated to the community or provided upon request.

\section{Interlibrary Cooperation *}

$\begin{array}{llll}1 & 2 & 3\end{array}$ The library engages in and seeks interlibrary cooperative activities which enhance the qualities of its services and benefit its interests. The costs of these services are equitably distributed among the cooperating institutions

$45 \quad 6 \quad$ The library engages in interlibrary cooperative activities which enhance the quality of its services and benefit its interests. However, the benefits of these services do not always balance their costs.

$\begin{array}{llll}7 & 8 & 9 & \text { The library engages in interlibrary }\end{array}$ cooperative activities, but should im- 
prove its use of these services, and/or their cost-effectiveness.

101112 The library does not seek or engage in interlibrary activities although services are available which would enhance the quality of its services and benefit its interests.

\section{J. Bill of Rights*}

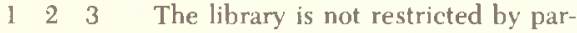
tisan or doctrinal disapprovals in its selection of library materials, upholds the user's right of access to information, and has college support for the "Library Bill of Rights."

456 Partisan or doctrinal disapprovals seldom affect the selection of library materials or the user's access to information. Usually the "Library Bill of Rights" is supported by the library and the college.

$\begin{array}{llll}7 & 8 & 9 & \text { The library supports the provisions }\end{array}$ of the "Library Bill of Rights," but the college does not always support these rights.

101112 The library excludes materials or restricts access to information contrary to the provisions of the "Library Bill of Rights," and does not seek college support of the policy.

\section{Standard 8: Budget}

8 The college librarian shall have the responsibility for preparing, defending, and administering the library budget in accord with agreed-upon objectives.

8.1 The amount of the library appropriation shall express a relationship to the total institutional budget for educational and general purposes.

8.2 The librarian shall have sole authority to apportion funds and initiate expenditures within the library approved budget, in accord with institutional policy.

8.3 The library shall maintain such internal accounts as are necessary for approving its invoices for payment, monitoring its encumbrances, and evaluating the flow of its expenditures.

\section{A. Budget Contents*}

$\begin{array}{llll}1 & 2 & 3 & \text { The budget of the library program }\end{array}$ developed by the librarian in consultation with library staff and college administrators reflects the library's priorities and objectives.

456 The budget of the library program developed by the librarian generally reflects most of the library's objec-

*Circle only one of the twelve numbers. tives. Several allotments do not conform to program priorities.

$\begin{array}{llll}7 & 8 & 9 & \text { The library budget partially reflects }\end{array}$ the library's objectives and priorities. The budgeting process requires revision.

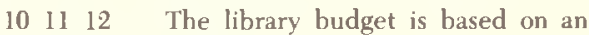
arbitrary or undefined allotment of funds with minimal reference to the library's objectives and priorities. The budgeting process requires major revision.

\section{B. Financial Support Requirements*}

123 The library's annual appropriation, exclusive of capital and physical maintenance costs, is at least 6 percent of the college's total educational and general expenditures.

456 The library's annual appropriation, exclusive of capital and physical maintenance costs, is 5 to 6 percent of the college's total educational and general expenditures.

$\begin{array}{llll}7 & 8 & 9 & \text { The library's annual appropriation, }\end{array}$ exclusive of capital and physical maintenance costs, is 4 to 5 percent of the college's total educational and general expenditures.

$\begin{array}{llll}10 & 11 & 12 & \text { The library's annual appropriation, }\end{array}$ exclusive of capital and physical maintenance costs, is below 4 percent of the college's total educational and general expenditures.

\section{Fiscal Accountability*}

$\begin{array}{llll}1 & 2 & 3 & \text { Regular reports reflect the status of }\end{array}$ allocations, encumbrances, and expenditures, and support sound practices of planning and control.

456 Reports reflecting the status of library accounts are issued periodically, but could be improved in scope, content, or frequency to support the administrative process.

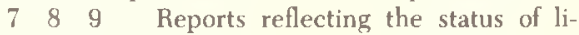
brary accounts are inadequate in scope and content, and/or issued too irregularly to provide accountability and support the administrative process.

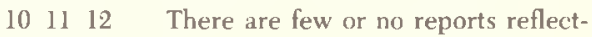
ing the status of library accounts, or those that exist fail the test of fiscal accountability.

\section{Proflle SHEET}

This chart [fig. 1] is provided to tabulate and summarize the judgments recorded on the Evaluative Checklist. To develop a profile, transfer the marks from each item of the checklist to this sheet. Connect the marked circles by straight 


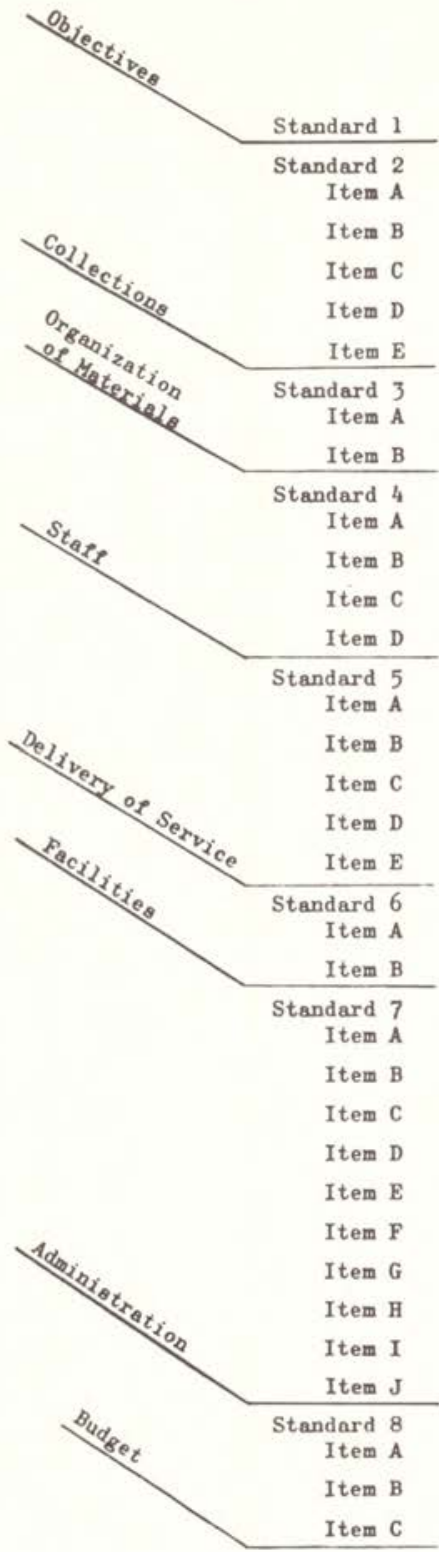

Strong

Mark only one of the twelve boxes

Weak

$\begin{array}{llllllllllll}1 & 2 & 3 & 4 & 5 & 6 & 7 & 8 & 9 & 10 & 11 & 12 \\ 1 & 2 & 3 & 4 & 5 & 6 & 7 & 8 & 9 & 10 & 11 & 12 \\ 1 & 2 & 3 & 4 & 5 & 6 & 7 & 8 & 9 & 10 & 11 & 12 \\ 1 & 2 & 3 & 4 & 5 & 6 & 7 & 8 & 9 & 10 & 11 & 12 \\ 1 & 2 & 3 & 4 & 5 & 6 & 7 & 8 & 9 & 10 & 11 & 12 \\ 1 & 2 & 3 & 4 & 5 & 6 & 7 & 8 & 9 & 10 & 11 & 12\end{array}$

$\begin{array}{llllllllllll}1 & 2 & 3 & 4 & 5 & 6 & 7 & 8 & 9 & 10 & 11 & 12\end{array}$

$\begin{array}{llllllllllll}1 & 2 & 3 & 4 & 5 & 6 & 7 & 8 & 9 & 10 & 11 & 12\end{array}$

$\begin{array}{llllllllllll}1 & 2 & 3 & 4 & 5 & 6 & 7 & 8 & 9 & 10 & 11 & 12\end{array}$

$\begin{array}{llllllllllll}1 & 2 & 3 & 4 & 5 & 6 & 7 & 8 & 9 & 10 & 11 & 12\end{array}$

$\begin{array}{llllllllllll}1 & 2 & 3 & 4 & 5 & 6 & 7 & 8 & 9 & 10 & 11 & 12\end{array}$

$\begin{array}{llllllllllll}1 & 2 & 3 & 4 & 5 & 6 & 7 & 8 & 9 & 10 & 11 & 12\end{array}$

$\begin{array}{llllllllllll}1 & 2 & 3 & 4 & 5 & 6 & 7 & 8 & 9 & 10 & 11 & 12\end{array}$

$\begin{array}{llllllllllll}1 & 2 & 3 & 4 & 5 & 6 & 7 & 8 & 9 & 10 & 11 & 12\end{array}$

$\begin{array}{llllllllllll}1 & 2 & 3 & 4 & 5 & 6 & 7 & 8 & 9 & 10 & 11 & 12\end{array}$

$\begin{array}{llllllllllll}1 & 2 & 3 & 4 & 5 & 6 & 7 & 8 & 9 & 10 & 11 & 12\end{array}$

$\begin{array}{llllllllllll}1 & 2 & 3 & 4 & 5 & 6 & 7 & 8 & 9 & 10 & 11 & 12\end{array}$

$\begin{array}{llllllllllll}1 & 2 & 3 & 4 & 5 & 6 & 7 & 8 & 9 & 10 & 11 & 12\end{array}$

$\begin{array}{llllllllllll}1 & 2 & 3 & 4 & 5 & 6 & 7 & 8 & 9 & 10 & 11 & 12\end{array}$

$\begin{array}{llllllllllll}1 & 2 & 3 & 4 & 5 & 6 & 7 & 8 & 9 & 10 & 11 & 12\end{array}$

$\begin{array}{llllllllllll}1 & 2 & 3 & 4 & 5 & 6 & 7 & 8 & 9 & 10 & 11 & 12\end{array}$

$\begin{array}{llllllllllll}1 & 2 & 3 & 4 & 5 & 6 & 7 & 8 & 9 & 10 & 11 & 12\end{array}$

$\begin{array}{llllllllllll}1 & 2 & 3 & 4 & 5 & 6 & 7 & 8 & 9 & 10 & 11 & 12\end{array}$

$\begin{array}{llllllllllll}1 & 2 & 3 & 4 & 5 & 6 & 7 & 8 & 9 & 10 & 11 & 12\end{array}$

$\begin{array}{llllllllllll}1 & 2 & 3 & 4 & 5 & 6 & 7 & 8 & 9 & 10 & 11 & 12\end{array}$

$\begin{array}{llllllllllll}1 & 2 & 3 & 4 & 5 & 6 & 7 & 8 & 9 & 10 & 11 & 12\end{array}$

$\begin{array}{llllllllllll}1 & 2 & 3 & 4 & 5 & 6 & 7 & 8 & 9 & 10 & 11 & 12\end{array}$

$\begin{array}{llllllllllll}1 & 2 & 3 & 4 & 5 & 6 & 7 & 8 & 9 & 10 & 11 & 12\end{array}$

$\begin{array}{llllllllllll}1 & 2 & 3 & 4 & 5 & 6 & 7 & 8 & 9 & 10 & 11 & 12 \\ 1 & 2 & 3 & 4 & 5 & 6 & 7 & 8 & 9 & 10 & 11 & 12 \\ 1 & 2 & 3 & 4 & 5 & 6 & 7 & 8 & 9 & 10 & 11 & 12\end{array}$

Fig. 1

Profile Sheet 
lines. Then turn the sheet to a horizontal position to observe the resulting graph. Interpretive guidelines are provided [below]

\section{USE of The Profjle SheET}

Interpreting evaluations recorded on one profile sheet is a relatively simple task; summarizing and describing a number of profile sheets requires the application of regular frequency distributions. To construct such a distribution-

1. List every score value in the first column (denoted by symbol $\mathrm{X}$ ) with the lowest number at the top.

2. Note the frequency (denoted by symbol f) of each score (the number of times a given score was obtained) to the right of the score in the second column of the table.

The table reveals at a glance how often each score was obtained; modalities, groupings, and skewings are easily identified. The scores could also be recorded in a grouped frequency distribution, using interval sizes of 4 , although loss of information will occur with such groupings since they will not provide the exact value of each score.

\section{APPENDIX}

Editor's Note: Appendix $I$, referred to in Formula $A$, and Appendix $I$, in Formula $C$, are published in the 1975 "Standards for College Libraries" (College \& Research Libraries News 36:299-301 [Oct. 1975]).

\section{FORMULA A-}

The formula for calculating the number of relevant print volumes (or microform volume-equivalents) to which the library should provide prompt access is as follows (to be calculated cumulatively):

1. Basic Collection

2. Allowance per FTE Faculty Member

3. Allowance per FTE Student

4. Allowance per Undergraduate Major or Minor Field ${ }^{\circ}$

5. Allowance per Masters Field, When No Higher Degree is Offered in the Field"

6. Allowance per Masters Field, When a Higher Degree is Offered in the Field ${ }^{\circ}$

7. Allowance per 6th-year Specialist Degree Field ${ }^{\circ}$

8. Allowance per Doctoral Field

85,000 vols.

100 vols.

15 vols. 350 vols.

6,000 vols.

3,000 vols.

6,000 vols.

25,000 vols.

A "volume" is defined as a physical unit of any printed, typewritten, handwritten, mimeographed, or processed work contained in one binding or portfolio, hardbound or paperbound, which has been cataloged, classified, and/or otherwise prepared for use. For purposes of this calculation microform holdings should be included by converting them to volume-equivalents. The number of volume-equivalents held in microform should be determined either by actual count or by an averaging formula which considers each reel of microform as one, and five pieces of any other microformat as one volume-equivalent.

Libraries which can provide promptly 100 percent as many volumes or volume-equivalents as are called for in this formula shall, in the matter of quantity, be graded A. From 80-99 percent shall be graded $B$; from 65-79 percent shall be graded C; and from 50-64 percent shall be graded D.

\footnotetext{
- See Appendix I, "List of Fields."
} 


\section{FORMULA B-}

The number of librarians required by the college shall be computed as follows (to be calculated cumulatively):

For each 500 , or fraction thereof, FTE students up to 10,000

1 librarian

For each 1,000 or fraction thereof, FTE students above 10,000

1 librarian

For each 100,000 volumes, or fraction thereof, in the collection

1 librarian

For each 5,000 volumes, or fraction thereof, added per year

1 librarian

Libraries which provide 100 percent of these formula requirements can, when they are supported by sufficient other staff members, consider themselves at the A level in terms of staff size; those that provide 75-99 percent of these requirements may rate themselves as B; those with 55-74 percent of requirements qualify for a $C$; and those with 40-54 percent of requirements warrant a $D$.

\section{FORMULA C-}

The size of the college library building shall be calculated on the basis of a formula which takes into consideration the size of the student body, requisite administrative space, and the number of physical volumes held in the collections. In the absence of consensus among librarians and other educators as to the range of non-book services which it is appropriate for libraries to offer, no generally applicable formulas have been developed for calculating space for them. Thus, space required for a college library's non-book services and materials must be added to the following calculations:

a. Space for readers. The seating requirement for the library of a college wherein less than fifty percent of the FTE enrollment resides on campus shall be one for each five FTE students; the seating requirement for the typical residential college library shall be one for each four FTE students; and the seating requirements for the library in the strong, liberal arts, honors-oriented college shall be one for each three FTE students. In any case, each library seat shall be assumed to require twenty-five square feet of floor space.

b. Space for books. Space required for books depends in part upon the overall size of the book collection, and is calculated cumulatively as follows:

For the first 150,000 volumes

Square Feet/Volume

For the next 150,000 volumes

0.10

0.09

For the next 300,000 volumes

0.08

For holdings above 600,000 volumes

0.07

c. Space for administration. Space required for such library administrative activities as acquisition, cataloging, staff offices, catalogs, and files shall be one-fourth of the sum of the spaces needed for readers and books as calculated under (a) and (b) above.

This tripartite formula indicates the net assignable area necessary for all library services except for non-book services. (For definition of "net assignable area" see "The Measurement and Comparison of Physical Facilities for Libraries," produced by ALA's Library Administration Division. See Appendix II.) Libraries which provide 100 percent as much net assignable area as is called for by the formula shall qualify for an A rating as regards quantity; 75-99 percent shall warrant a $B ; 60-74$ percent shall be due a $C$; and $50-59$ percent shall warrant a $D$.

Editors Note: ACRL Members may order single copies of the Evaluative Checklist by sending a selfaddressed label and $\$ .30$ in postage to the ACRL office. Nommembers should include $\$ 1$ uith their order. 